\title{
LATVIEŠU TRIMDAS NOZĪMĪGĀKĀS POLITISKĀS AKCIJAS: BALTIJAS BRĪVĪBAS UN MIERA KUG̣A (1985) PIEMẼRS
}

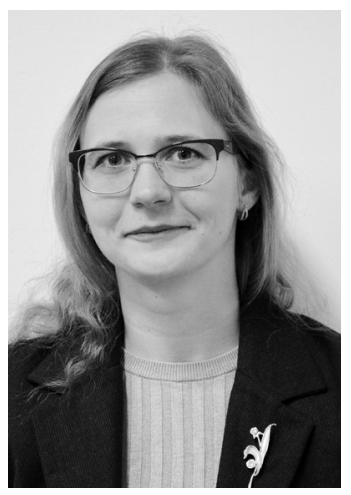

Kristīne Beḳere ir ieguvusi maǵistra grādu vēstures zinātnē (2009, Greifsvaldes Universitāte, Vācija) un pašlaik ir doktora zinātniskā grāda pretendente Latvijas Universitātē. LU Latvijas vēstures institūta pētniece un Kuld̄̄gas novada muzeja pētniece. Pētnieciskās intereses: attieksme pret Latvijas valstiskumu diasporā (pirms Otrā pasaules kara) un trimdā, latviešu trimdas politiskās aktivitātes, baltiešu sadarbība trimdā.
Raksturvārdi: trimda, Baltijas brīvības un miera kugis, Latvijas neatkarības ideja, politiskās aktivitātes, Helsinku Nobeiguma akts.

\section{Ievads}

Latviešu trimda, resp., latvieši, kuri Otrā pasaules kara bēgḷu kustības rezultātā pēc kara atradās ārpus Latvijas teritorijas un apmetās uz pastāvīgu dzīvi "brīvajā pasaulē", nesamierinājās ar Latvijas pretlikumīgo pievienošanu Padomju Savienībai. Visu savu pastāvēšanas laiku no Otrā pasaules kara beigām līdz pat Latvijas Republikas neatkarības atjaunošanai trimda aktīvi darbojās sabiedrisko attiecību un politiskā lobija jomās savās mītnes zemēs, uzturot dzīvu Latvijas neatkarības ideju un cenšoties veicināt Latvijas valstiskās neatkarības atjaunošanu. Gan ārēju (saspīlējumi un atslābumi aukstā kara procesos), gan iekšēju (paaudžu nomaiņa trimdā) faktoru ietekmē kopš 70. gadu vidus trimdas politiskās aktivitātes bija aktivizējušās starptautiskā mērogā.
Raksta mērkis ir analizēt vienu no trimdas publicitātes zin̄ā veiksmīgākajām politiskajām akcijām - 1985. gadā notikušo Baltijas brīvības un miera kuǵa braucienu, pievēršot galveno uzmanību brauciena organizēšanai un norisei, kā arī sasniegto rezultātu un ietekmes analīzei.

Baltijas brīvības un miera kuğa brauciens kā loti spilgta trimdas dzīves epizode ir salīdzinoši daudz aprakstîts publicistikā un atminuu stāstos ${ }^{1}$ gan trimdas laikā, gan pēc neatkarības atgūšanas. Tiesa gan, pētnieki varētu vēlēties, lai savās atmin̄ās rakstītāji vairāk un detalizētāk pakavētos nevis tikai pie emocionāli sakāpinātākajiem notikumiem, piem., lielākajām demonstrācijām, bet tieši pie pasākuma plānošanas un organizēšanas aizkulisēm, kuras grūti rekonstruēt no citiem avotu veidiem. Uz savu personīgo pieredzi balstītu rakstu par šo akciju ir publicējis tās organizācijas komitejas

\footnotetext{
1 Nyet Nyet Soviet 2018.
} 
vadītājs Māris Graudiņš̌ $\breve{ }^{2}$ kuǵa brauciena divdesmitgadei veltîtu īsu pārskatu publicējusi Lilita Zalıalne ${ }^{3}$. Šis raksts ir mēginājums uz arhīvos atrodamo dokumentu un citu tālaika liecību pamata papildināt par braucienu jau zināmo ar jaunu informāciju, rekonstruēt brauciena organizēšanas, un īpaši finansēšanas, procesus, kā arī secīgi atspoguḷot brauciena norises galvenos notikumus un nobeigumā iespēju robežās izvērtēt š̄̄ brauciena vietu trimdas politisko aktivitāšu vēsturē.

Arhīvu materiāli par šo akciju diemžēl ir loti izkaisīti un atrodas trimdas dokumentu krātuvēs daudzviet pasaulē. Šajā rakstā izmantoti materiāli no Latvijas Nacionālā arhīva Latvijas Valsts arhīva, Latviešu dokumentācijas centra Lielbritānijā Straumēnos, Minesotas Universitātes Imigrācijas vēstures pētniecības centra arhīva (Immigration History Research Center - IHRC) un ALA biroja arhīva Rokvilā, ASV. Neapšaubāmi, arī citos arhīvos iespējams atrast dokumentus par Baltijas brīvības un miera kuǵa akciju.

\section{Baltijas brīvības un miera kuğa ideja}

Baltijas brīvības un miera kuǵa brauciena idejas autors bija Zviedrijā dzīvojošais latviešu publicists, žurnālists un aktīvs trimdas sabiedriskais darbinieks Vilnis Zaļkalns. Ideja par kuğa braucienu kā politisku manifestāciju, šķiet, izskanējusi jau krietni agrāk, 70. gados latviešu jauniešu neformālās sarunās Eiropas Latviešu jaunatnes apvienības kongresos. ${ }^{4}$ Pati ideja par Baltijas jūrā esoša kuğa izmantošanu kā platformu kādām ar Baltijas valstīm saistītām aktivitātēm ir vēl senāka - 60. gadu sākumā tika apsvērta ideja par kuğa izmantošanu kā bāzi radio raidītājam Baltijas Balss, kas gan netika izveidots. ${ }^{5}$ Šai sākotnēji plānotajai radio kuǵa idejai gan ir pavisam cits raksturs nekā divdesmit gadus vēlāk tiešām īstenotajai Baltijas brīvības un miera kuǵa politiskajai akcijai, tādēḷ abu notikumu starpā saskatāma drīzāk idejiskas iedvesmošanās saikne, nevis tieša pēctecība.

\footnotetext{
2 Graudinš 2011.

Zalıalne 2005, 45-46.

4 Graudiņš 2011, 252.

5 Sk. Ekmanis 2007.
}

Kug̣a braucienam tika izvirzīti vairāki mērḳi, kuri visi bija saistīti ar ideju par Latvijas neatkarības atjaunošanu. Brauciena galvenais mērḳis bija "Igaunijas, Latvijas un Lietuvas tuvākiem kaimiņiem atgādināt, ka miers Eiropā nav dalāms no cilvēka tiesību respektēšanas un demokrātijas atjaunošanas trīs PSRS okupētajās Baltijas republikās" . Citas akcijas rīkotāju izvirzītās prasības bija atbrīvot Baltijas valstis no PSRS atomieročiem, izvest okupācijas varas militāros spēkus no Baltijas valstīm. Organizatori vēlējās "radīt situāciju, kad vismaz uz dažām dienām Baltijas jautājums izvirzās pasaules masu mediju starmešu gaismā", kā arī cerēja, ka šāda akcija varētu "izraisīt atbalsis un stimulēt līdzịga paveida idejisku kustību okupētajās Baltijas zemēs".?

Akcijas dalībnieki izteica savu atbalstu baltiešu disidentiem, kas tikuši apcietināti par vides aizsardzības jautājumu aktualizēšanu un pieprasīja pārtraukt PSRS īstenotos cilvēktiesību un pašnoteikšanās tiesību pārkāpumus Baltijas valstīs. ${ }^{8}$ Baltijas valstu vides aizsardzības problēma bija viens no tiem tematiskajiem jautājumiem, kuru vēlējās aktualizēt brauciena organizatori. Vides jautājums saistījās gan ar prasībām atbrīvot Baltijas reǵionu no kodolieročiem, gan arī ar atbalstu disidentiem.

Tādējādi šajā politiskajā akcijā trimdas jaunieši pievērsās līdz tam trimdas politiskajās akcijās netipiski plašam jautājumu lokam: vides problēmām, miera kustībai, atomieroču draudam, cilvēktiesību ievērošanas problēmām Austrumeiropā u. c., izceļot tautas pašnoteikšanās tiesības kā pamatu un garantu visām citām tiesībām un brīvībām. Tāpat organizatori cerēja, ka kuǵa brauciens palīdzēs izveidot personīgus kontaktus trimdas baltiešu jauniešu starpā, kas būtu pamats baltiešu sadarbības turpināšanai, un izvirzīja arī baltiešu - un eventuāli arī Baltijas valstu - sadarbības apspriešanu par vienu no brauciena uzdevumiem. ${ }^{9}$

6 Cipulis 2001, 127.

Baltiešu brīvības un miera kuğis 1984 .

8 Baltic Peace and Freedom Cruise Objectives. 2253-1-15, 35.

9 A Baltic Peace and Freedom Cruise. LNA LVA, 2253-1-16, 3. 


\section{Brauciena organizēšana un finansēšana}

Kuǵa brauciena plānošana sākās 1983. gada oktobrī V. Zaḷalna un M. Graudina vadībā. V. Zaḷkalns koordinēja plānošanas darbus Zviedrijā, organizēja demonstrācijas utt. ${ }^{10}$, bet M. Graudiņš l̦oti veiksmīgi spēja pārliecināt lielākās trimdas organizācijas - PBLA, Daugavas Vanagus (turpmāk - DV) u. c. - par atbalstu šo trimdas jauniešu izplānotajam pasākumam.

Tāda apjoma akcijas īstenošanai bija nepieciešams piesaistīt arī lietuviešus un igauņus. Pateicoties M. Graudiņam, tika izveidota starptautiska baltiešu jauniešu rīcības komiteja, un Baltijas brīvības un miera kuǵa braucienu organizēja visu trīs Baltijas valstu trimdas jauniešu organizācijas ciešā sadarbībā. Attiecīgi arī pasākuma rīcības komiteju vadīja visu trīs Baltijas valstu pārstāvji: Ģintars Grušs (Gintaras Grušas) pārstāvēja lietuviešu trimdiniekus, M. Graudin̄š - latviešus, Marts Kikerpū (Mart Kikerpuu) - igauņus. ${ }^{11}$ No latviešu vidus brauciena plānošanā un organizēšanā aktīvi iesaistījās arī brauciena idejas autors V. Zaḷkalns, Juris Kaža, Imants Gross un citi latvieši. Jāatzīmē arī Mārča Štāla loma brauciena rīkošanā. Viṇš bija atbildīgs par brauciena plānošanas administratīvo pusi, ieskaitot kuğa īres līguma slēgšanu (Padomju Savienība izdarīja zināmu spiedienu uz kuǵa ìpašniekiem, draudot šo līgumu lauzt). ${ }^{12}$

Viens no galvenajiem priekšnoteikumiem, lai Brīvības un miera kug̣a akcija varētu sasniegt savus mērķus, bija iespējami plaši pievērst sabiedrības uzmanību šai akcijai un līdz ar to Baltijas valstīm un to problēmām. Lai to panāktu, loti svarīgi bija plānot un pielietot publicitātes stratēgijas un principus darbam ar medijiem. Pirms kuǵa brauciena latviešu trimdas sabiedriskais darbinieks un žurnālists J. Kaža sagatavoja šādu plānošanas dokumentu, iekḷaujot iespējamo ieinteresēto mediju apskatu un ieteikumus publicitātes nodrošināšanai. Darbības plāns paredzēja vispirms izsūtīt medijiem vispārīgu preses paziņojumu,

10 Graudiņš 2011, 252-255.

11 Letter from Baltic Council to Estonian, Latvian, Lithuanian Organziations (20.11.1984). Latviešu dokumentācijas centrs Lielbritānijā, Baltic Council materiāli.

12 Graudiṇš 2011, 252. kas dotu priekšstatu par pasākuma saturu un attiecīgi par to, kāda ir tā potenciālā vērtība kā ziṇām. Lai pievilinātu žurnālistus piedalīties arī pašā braucienā, J. Kaža ieteica uzsvērt, ka uz kuğa ir pieejama sakaru aparatūra (kas l̦autu žurnālistiem noraidīt ziņas tieši no kuğa, tātad nodrošināt aktuālas reportāžas). Visbeidzot, plāns paredzēja presei nosūtìt biežus un regulārus atgādinājumus par kruīzu katrreiz, kad tiktu papildinātas vai precizētas kādas jaunas būtiskas akcijas detaḷas, tādā veidā pastāvīgi atgādinot par pasākumu. Kā vienu no ieinteresēšanas metodēm plāns ieteica šiem atgādinājumiem pievienot îsu faktu apkopojumu par dažādiem ar Baltijas valstīm saistītiem aspektiem, kas var būt interesanti pasaules medijiem, piem., Baltijas valstis un vide, Baltijas valstis un militārā drošība, baltiešu folklora $u$. tml., vienlaikus tika norādīts, ka par vienu vai otru no šiem jautājumiem kruīza laikā tiks runāts sīkāk kādā konkrētā lekcijā vai diskusijā. ${ }^{13}$

Baltijas brīvības un miera kuǵa akcijas īstenošana prasīja ievērojamus finanšu līdzekḷus. Kopējās pasākuma izmaksas (ieskaitot kuğa īri, kuǵa degvielu un ostas nodevas, reklāmas materiālus, rīkošanas izmaksas, ēdināšanu, telpu īri Kopenhāgenā un Stokholmā, transporta izdevumus u. c.) sākotnēji, projektu plānojot, tika lēstas ap 165500 ASV dolāru ${ }^{14}$, vēlāk pat ap 235000 dolāru $^{15}$.

Dalıu brauciena izmaksu sedza paši tā dalībnieki. Piedalīšanās braucienā bija par maksu, un tā izmaksas bija 300 ASV dolāru jauniešiem vecumā līdz 30 gadiem, bet pārējiem 350 vai 400 ASV dolāru atkarībā no kajītes tipa. ${ }^{16}$ Starptautiskās preses pārstāvju un uzaicināto viesu dalības izmaksas tika segtas no kopējiem akcijas rīkošanas līdzekḷiem. Ievērojamu finansiālu atbalstu sniedza lielākās baltiešu trimdas organizācijas. PBLA ziedoja 30000 dolāru, "vairākus tūkstošus" igauņu un lietuviešu centrālās organizācijas Kanādā

13 Press contacts, Baltic peace and freedom cruise, by Juris Kaza. LNA LVA, 2253-1-16, 7-9.

14 Tenative budget: Baltic Peace and Freedom Cruise 1985. LNA LVA, 2253-1-16, 5.

15 A conservative budget (tentative). LNA LVA, 2253-1-16, 23.

16 Baltic Peace and freedom cruise faktu apkopojums. LNA LVA, 2253-1-15, 34. 
un Lietuvas atbrīvošanas komiteja, DV Centrālā valde 500 dolāru $^{17}$, ASV nodaḷa - 1500 dolāru un dažādas citas latviešu, lietuviešu un igauṇu organizācijas mazākas summas. ${ }^{18}$

Pārējos projekta īstenošanai nepieciešamos līdzekḷus ieguva ziedojumu ceḷā, rīkojot dažādas ziedojumu vākšanas akcijas dažādās valstīs un izlozes. DV Centrālā valde pēc M. Graudiņa ierosinājuma izdeva Baltijas brīvības un miera kuğa akcijai veltītu pastmarku 3000 loksnīšu tirāžā. 1000 no tām tika nodotas kuǵa brauciena organizatoru rīcībā, bet atlikušās 2000 - sadalītas pa dažādu valstu DV nodaḷām izplatīšanai. Marku tirdzniecība ienesa 4736 vācu marku lielu peḷnu, kuru DV nodeva brauciena rīkotājiem tā finansēšanai. ${ }^{19}$

Lai iegūtu līdzekḷlus 1985. gada vasarā plānotajām daudzajām politiskajām akcijām, arī Brīvības nedēlai - Kopenhāgenas tribunālam un Baltijas brīvības un miera kuǵa braucienam, PBLA 1985. gadā rīkoja plašu izlozi visās latviešu trimdas zemēs. Ar latviešu organizāciju un draudžu palīdzību uz vietām tika izplatītas loterijas biḷetes, kuras trimdas latvieši tika aicināti gan iegādāties paši, gan arī izplatīt pazin̄ām cittautiešiem savās mītnes zemēs. ${ }^{20}$ Loterijas galvenais laimests bija ceḷojums apkārt pasaulei divām personām jeb 10000 ASV dolāru, otrs laimests - ceḷojums uz Havaju salām divām personām jeb 2500 dolāru un trešais - Baltijas brīvības un miera kug̣a brauciens divām personām jeb 1000 dolāru. Kopumā tika pārdotas izlozes biḷetes par samērā lielu summu - 95600 ASV dolāru. Lielākā daḷa biḷešu bija pārdotas ASV, kopsummā par 45000 dolāru. Venecuēlā un Austrālijā pārdoto biḷešu summa bija 14560 dolāru katrā, Kanādā - 11000 dolāru, Anglijā, Zviedrijā un Vācijā ieņēmumi bija trīs līdz četri tūkstoši katrā, Norvēǵijāa Dānijāâ, Itālijā un Holandē ieņēmumi nesasniedza 100 dolārus. Loterijas galveno balvu ieguva 80 gadus vecā Erna Kalniņa

${ }^{17}$ Baltic Peace and Freedom cruise Major support organizations. LNA LVA, 2253-1-15, 37.

${ }^{18}$ Graudinšs 1985.

${ }^{19}$ Liepinina 1995, 74-81.

20 ALA valdes locekḷa A. Lamberga vēstule latviešu organizāciju un draudžu ASV vadīiājiem (30.04.1985.). LNA LVA, 2253-1-14, 12.
Kalifornijā. ${ }^{21}$ Atskaitot laimestu summas un precīzi nezināmu summu loterijas rīkošanas izmaksu segšanai, politisko akciju finansēšanai paredzētais atlikums no biḷešu pārdošanas jebkurā gadījumā bija diezgan ievērojams. Tādējādi akcija bija veiksmīga.

Papildus vispārējai ziedojumu vākšanai tika izveidots arī kuǵa brauciena stipendiju fonds. Ja kāds nevēlējās vai nevarēja braukt kruīzā pats, pastāvēja iespēja ziedot naudu brauciena stipendiju fondam. Turklāt organizatori solīja ievērot ziedotāju izteiktās vēlēšanās attiecībā uz potenciālajiem ziedojuma saņēmējiem un vēlmi "atbalstît braucējus, kas pieder zināmai akadēmiskai organizācijai, vecuma grupai, konfesijai utt." ${ }^{22}$. Trimdiniekiem attiecīgi bija iespēja ne tikai atbalstīt akciju kopumā, bet arī ziedot tieši, viņuprāt, nepieciešamas dalībnieku grupas piesaistīšanai šim braucienam, piem., konkrētas valsts vai pilsētas trimdas latviešu jauniešu ceḷa izmaksu segšanai u. tml.

\section{Brauciena norise}

Baltijas brīvības un miera kug̣a brauciens notika ar kug̣i Baltic Star, un tas ilga trīs dienas. Akcijas sagatavošanas gaitā tika apsvērts arī variants rīkot sešas dienas ilgu braucienu pa maršrutu Stokholma-Kopenhāgena-Baltijas valstu krasti-Helsinki-Stokholma, kas tādā gadījumā ḷautu nobraukt arī gar Lietuvas krastiem, nevis tikai gar Latvijas un Igaunijas krastiem, kā paredzēja īsākā trīs dienu celıjojuma versija. ${ }^{23}$ Dažādu iemeslu dēḷ sešu dienu versija tomēr tika atzīta par neīstenojamu un kā piemērotāka izvēlēta īsākā trīs dienu versija.

İstenotā brauciena maršruts veda no Stokholmas (izbraukšana 26. jūlija vakarā) pa Baltijas jūru starp Gotlandi un Baltijas valstu krastiem līdz Helsinkiem. Helsinkos kuğis 28. jūlijā uzkavējās zināmu laiku, un brauciens turpinājās tālāk no Helsinkiem atpakạ̣ uz

${ }^{21}$ PBLA Brīvības nedēlas izlozes laimētāji 1985.

22 Mārča Štāla informatīvs uzsaukums tautiešiem, Stokholma (06.1985.). LNA LVA, 2253-1-15, 28.

${ }^{23}$ Final draft proposal for the Baltic Peace \& Freedom cruise. ALA arhīvs birojā Rokvilā, kaste: Pasaules brīvo latviešu apvienība; mape: Baltic Freedom Cruise 1985. 


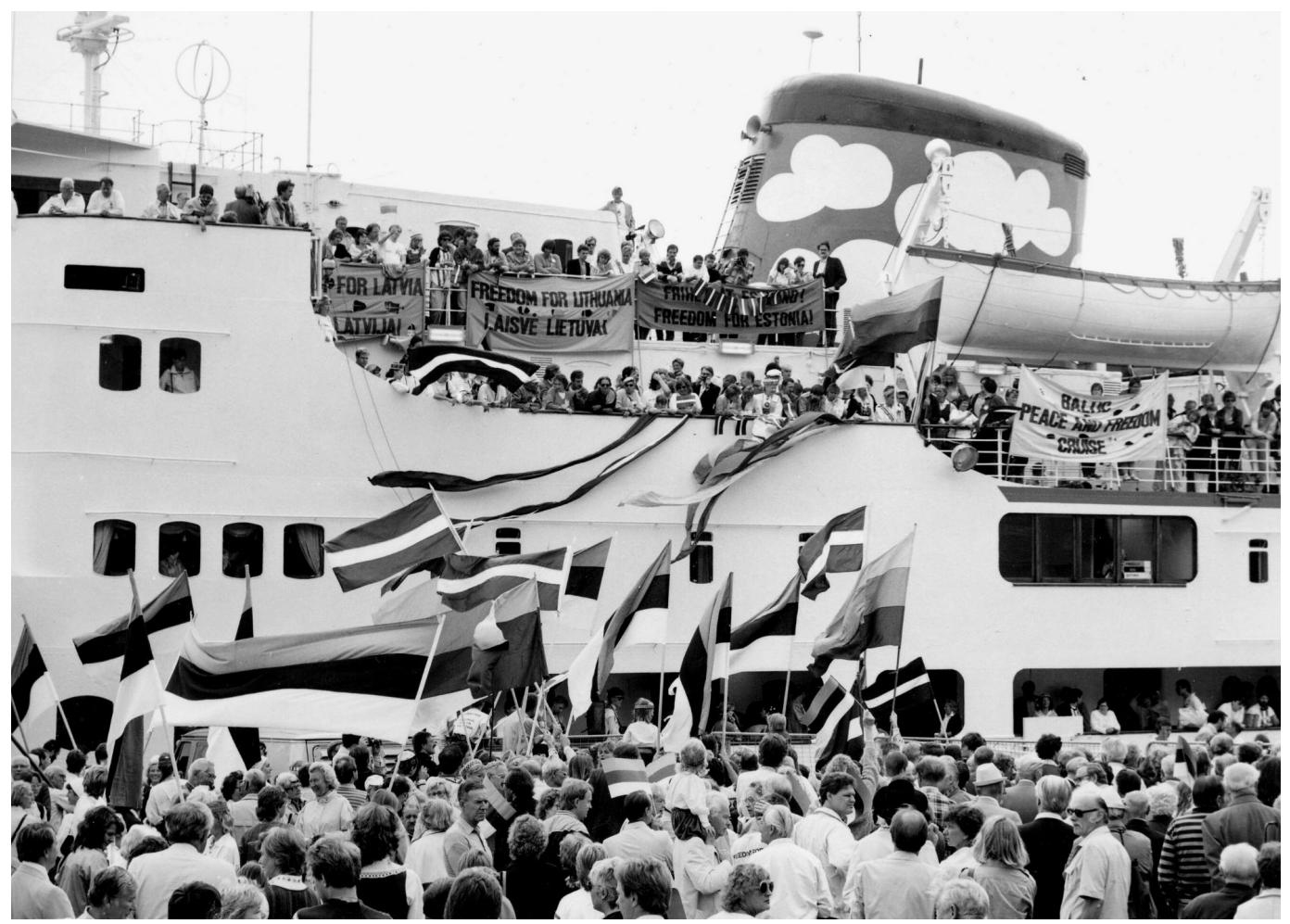

1. attēls. Baltijas brīvības un miera kugiis Stokholmas ostā 1985. gada 29. jūlijā.

Foto: Laimons Niedre, no muzeja Latvieši pasaulē krājuma

Stokholmu (iebraukšana Stokholmā 29. jūlijā). Stokholmā arī vēl nākamajās dienās notika pasākumi, kas bija saistîti ar kug̣a braucienu. ${ }^{24}$ Pasākuma kulminācijā 31. jūlijā un 1. augustā notika plašs baltiešu folkloras koncerts Stokholmas brīvdabas muzejā. ${ }^{25}$ Kuǵa braucienā piedalījās kopumā 206 latvieši, 55 lietuvieši un 40 igauņi, vairums no tiem jaunieši. Tāpat piedalījās arī ap 50 dažādu Rietumvalstu laikrakstu, radio un televīzijas pārstāvju un ap 20 politiḳu, zinātnieku, rakstnieku un mākslinieku. ${ }^{26}$

Pie Baltijas brīvības un miera kuğa pasākumu kopuma būtu jāpieskaita arī demonstrācija Kopenhāgenā 25. jūlijā paralēli Pasaules Baltiešu apvienības rīkotā Kopenhāgenas tribunāla norisei, kura simboliski ievadīja visu Baltijas brīvības un miera kuǵa akciju.

24 News Release. Baltic Peace and Freedom cruise. LNA LVA, 2253-1-15, 27.

25 Baltic Peace and Freedom Cruise program. LNA LVA, 2253-1-15, 35.

26 Zalikalne 2005, 45-46.
Demonstranti devās gājienā uz PSRS vēstniecību, kā arī noklausījās padomju disidenta Vladimira Bukovska runu. ${ }^{27}$

Kuǵa brauciena laikā tika īstenota plaša sarīkojumu programma: lekcijas, preses konference, diskusijas, pieminas, kā arī kultūras un izklaides sarīkojumi. Diskusiju dalībnieki izskatīja iespējas panākt brauciena organizatoru izvirzịto prasību īstenošanu un meklēja risinājumus pastāvošajai cilvēktiesību un pašnoteikšanās tiesību neievērošanas situācijai Baltijā. Diskusiju dalībnieki arī analizēja iespējamos scenārijus, kas varētu rezultēties ar miera un brīvības iedibināšanu Baltijas valstīs, un lūkoja izvērtēt, vai šādi scenāriji ir tikai gaisa pilis vai reālas iespējamības. ${ }^{28}$

27 Radio Free Europe/Radio Liberty B-wire news report (26.07.1985). IHRC, kolekcija: Baltic tribunal, mape: Radio Report manuscripts.

28 Baltic Peace and Freedom Cruise Rationale (06.1985). Māra Graudiña personīgais arhīvs. 


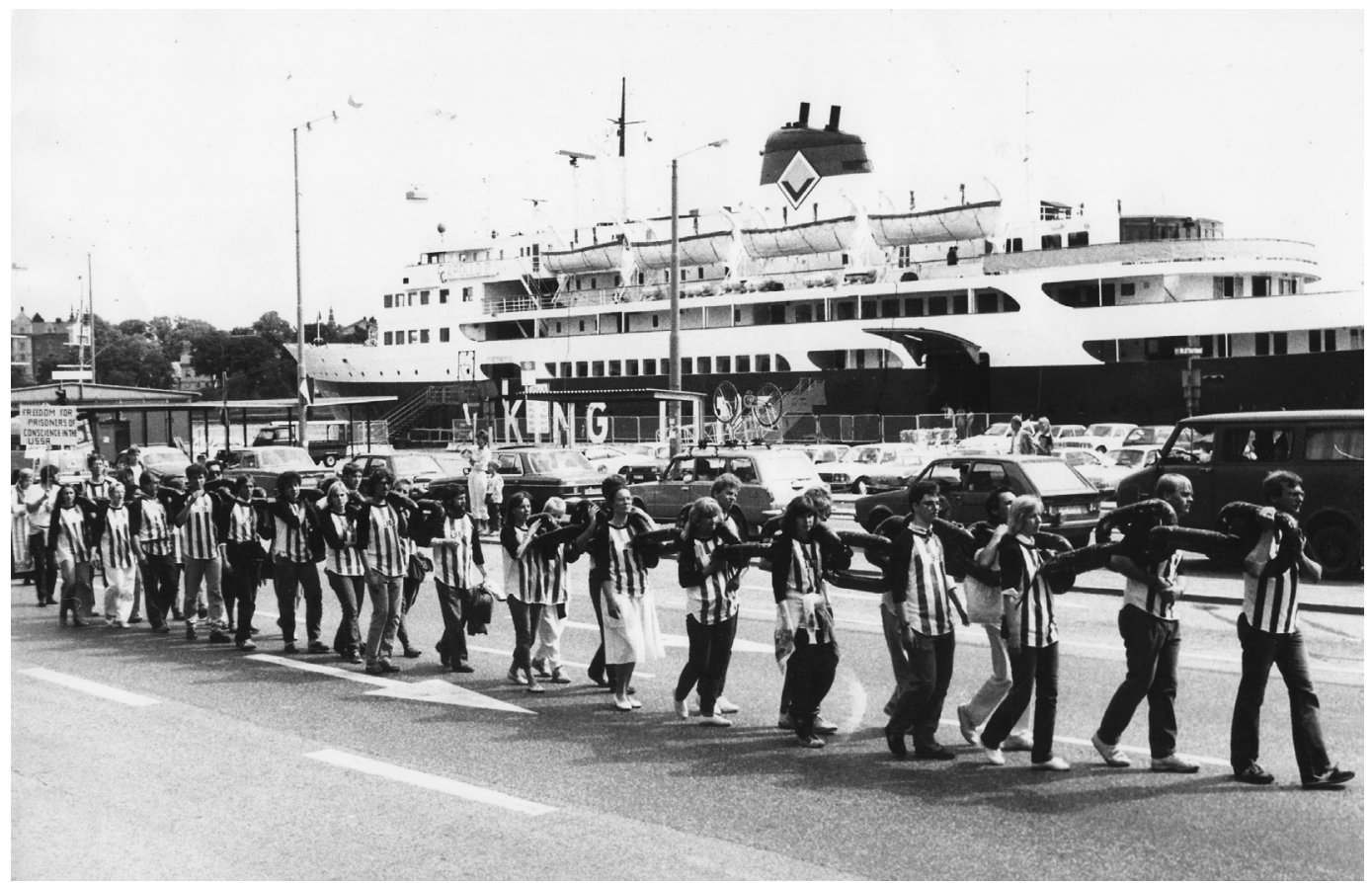

2. attēls. "Cietumnieku" gājiens pēc Baltijas brīvības un miera kuğa atgriešanās Stokholmā 1985. gada 29. jūlijā. Foto: Fricis Forstmanis, no muzeja Latvieši pasaulē krājuma

Diskusijās un semināros uz kuǵa klāja piedalījās ne vien baltiešu trimdinieki, bet arī tādas redzamas personības kā igauṇu izcelsmes Zviedrijas rakstnieks un politikiis Andress Kings (Andres Küng), bijušais Latvijas PSR Valsts drošības komitejas līdzstrādnieks Imants Lešinskis $^{29}$, krievu disidents un rakstnieks Vladimirs Bukovskis, zviedru vēsturnieks Kristians Gerners, bijušais Zviedrijas vicepremjers Pērs Ālmarks, bijušais politieslodzītais Gunārs Rode, Polijas Solidaritātes kustības pārstāvji u. c. ${ }^{30}$ Uz kuǵa klāja netālu no Gotlandes notika piemiņas brīdis baltiešu bēgḷiem, kas gāja bojā, laivās bēgot no Baltijas uz Zviedriju. Braucot gar Baltijas valstu krastiem, atsevišķus pieminas brīžus noturēja lietuviešu, vēlāk latviešu un naktī - igauņu trimdinieku grupas. ${ }^{31}$

Kug̣a brauciena starpposmā Helsinkos 28. jūlijā notika vairāki Eiropas drošības un sadarbības konferences pasākumi, kas bija veltīti

29 Baltic Peace and Freedom Cruise program. LNA LVA, 2253-1-15, 35.

30 Zaḷkalne 2005, 45.

31 Baltiešu dienas Skandināvijā 1985, 12.
Helsinku Nobeiguma akta parakstīšanas desmitgadei. Sarîkojumi tieši Helsinkos bija svarīgi, jo arī tematiski brauciena dalībnieku prasības saistījās ar Helsinku līguma noteikumos ierakstîto: iespēju mainīt robežas miermīlīgā ceḷā un cilvēktiesību ievērošanu. Helsinkos paredzētā demonstrācija attiecīgi arī bija iecerēta Helsinku Nobeiguma akta parakstǐšanas desmitgades atzīmēšanai. Tā bija pirmā oficiāli aț̣autā politiskā demonstrācija pēckara Somijā, kurā somu varas iestādes ḷāva publiski demonstrēt Baltijas valstu karogus. ${ }^{32}$ Līdz pat pēdējam brīdim pastāvēja šaubas, vai plānotā demonstrācija tiks atlauta, tomēr tā notika.

Kopumā attiecībā uz Baltijas brīvības un miera kuǵa akciju Somijas valdība bija spiesta ieturēt sarežǵīti sasniedzamu līdzsvaru starp attiecību nepasliktināšanu ar PSRS, kas varētu notikt, atḷaujot paredzētās akcijas, un demokrātiskai valstij piederīgo cilvēktiesību un pulcēšanās brīvības ievērošanu, kuras tiktu ierobežotas, aizliedzot šādu mierīgu demonstrāciju. Kompromisa meklējumos somu varas

32 Bohuslawsky 1985. 


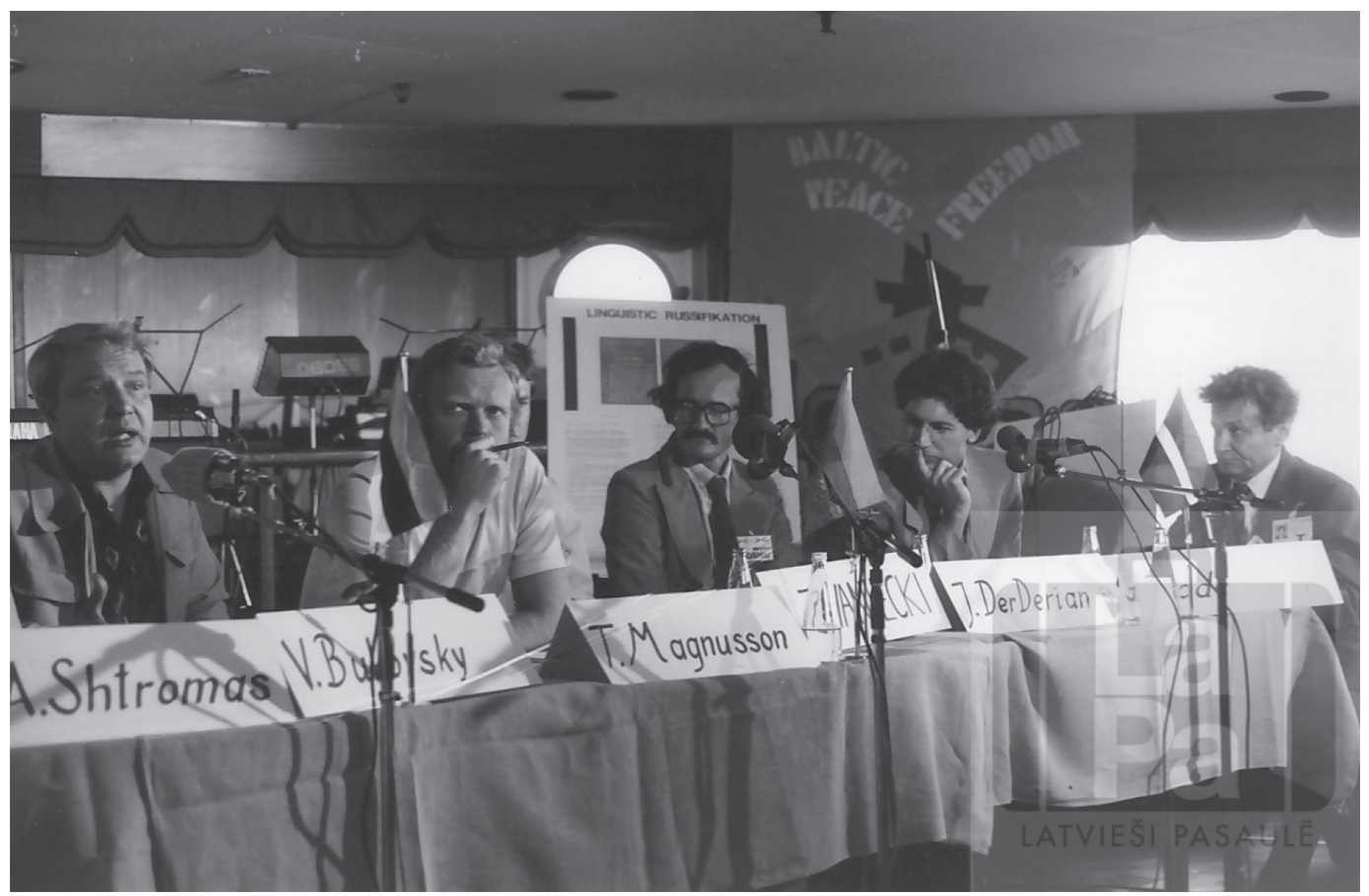

3. attēls. Paneḷdiskusija par mieru un cilvēku tiesībām Baltijas brīvības un miera kuğa akcijas laikā. Piedalās (no kreisās): Vladimirs Bukovskis (Vladimir Bukovskij) - padomju disidents un cilvēktiesību aizstāvis, zviedrs Tomass Magnusons (Tomass Magnusson), Andžejs Zvaņeckis (Andrzej Zwaniecki) - poḷu brīvās arodbiedrības Solidarność aktīvists, Džeimss Derderians (James DerDerian) - ASV politikas zinātnieks, Gunārs Rode - latviešu nacionālās pretošanās kustības dalībnieks, bijušais politieslodzītais, disidents.

Foto: Paulīne Riemere, no muzeja Latvieši pasaulē krājuma

iestādes izmain̄̄ja kruīza kuǵa piestātnes vietu, novirzot to no pasažieru ostas Helsinku centrā, kurā sākotnēji bija paredzēts piestāt, uz attālāko un daudz mazāk publisko industriālo ostu ${ }^{33}$, taču plānoto demonstrāciju aț̣āva. Somu varas iestāžu neviennozīmīgo attieksmi pret Baltijas brīvības un miera kuǵa akciju veicināja arī PSRS apgalvojumi, ka šis kruīzs varētu apdraudēt Helsinkos divas dienas vēlāk notiekošo sanāksmi, kura bija veltīta Helsinku Nobeiguma akta desmitgadei un kurā bija paredzēts piedalīties ārlietu ministriem no 35 valstīm, kas bija parakstījušas šo aktu. ${ }^{34}$

33 Radio Free Europe / Radio Liberty B-wire news report (26.07.1985). IHRC, kolekcija: Baltic tribunal, mape: Radio Report manuscripts.

34 Radio Free Europe / Radio Liberty B-wire news report "Finnish embarrassed over freedom cruise" (27.07.1985) (turpat).
Helsinku demonstrācija aizsākās ostā, un gājiens devās cauri pilsētai līdz Vecās baznīcas parkam (Old Church Park), kur atrodas piemineklis somiem, kuri piedalījušies Igaunijas neatkarības karā. Mediji atzīmēja, ka gājiena laikā populārākais sauklis bijis Nyet, nyet, Soviet!. Demonstrācija noritēja bez starpgadījumiem. Pie pieminekḷa runu teica vispirms Somijas Lauku partijas pārstāvis Sepo Karhu (Seppo Karhu), kam sekoja padomju disidenta V. Bukovska un A. Kinga runas. ${ }^{35}$

Medijos publicētajās ziņās aprakstīts, ka somi šo demonstrāciju uzṇēmuši l̦oti pozitīvi un tā noritējusi emocionāli sakāpinātā gaisotnē, daudziem somiem piedaloties demonstrācijā un jūtot līdzi Baltijas valstu liktenim.

\footnotetext{
35 Helsinki International Service in Finnish ziņu apkopojums LD281846 (28.07.1985) (turpat).
} 
Kopumā demonstrācijā un vainagu nolikšanā pie Igaunijas brīvības cīṇu atbalstītāju pieminekla varētu būt piedalījušies ap 2000 cilvēku. ${ }^{36}$ Nozīmīga bija šai demonstrācijai un kuğa akcijai kopumā veltītā reportāža Somijas televīzijā pusstundu garā raidījumā, turklāt šis raidījums bija redzams arī Tallinā. ${ }^{37}$

Pēc plānotās demonstrācijas beigām, 28. jūlija pēcpusdienā, baltieši sarīkoja arī iepriekš nepieteiktu nelielu demonstrāciju pie PSRS vēstniecības Helsinkos. Tās gaitā somu policija arī aizturēja vairākus cilvēkus, kas gan drīz vien tika atbrīvoti. ${ }^{38}$ Šo demonstrāciju aizsāka astoṇi baltiešu jaunieši, kuri klusējot staigāja šurpu turpu pa ietvi iepretim PSRS vēstniecībai ar populārajā "uzvaras" (Victory $-V$ ) žestā paceltām rokām. Demonstrācijas dalībnieku skaits pamazām pieauga līdz aptuveni 20-30 cilvēkiem, kā arī vairākiem simtiem skatītāju un žurnālistu. ${ }^{39}$

Politisko prasību formulēšana bija arī paša kug̣a brauciena dienaskārtībā. Uz kug̣a brauciena laikā tika izstrādāta un pieņemta Dānijas, Islandes, Norvēgijas, Somijas, Zviedrijas un PSRS valdībām adresēta rezolūcija Par mieru, drošību un cilvēktiesībām Ziemel̦valstīs un Baltijas valstīs. Deklarācija aicināja PSRS valdību ievērot starptautiskās vienošanās par cilvēktiesībām un pašnoteikšanās tiesībām un dot iespēju baltiešiem pašiem noteikt savu likteni. Ziemel̦valstu valdības savukārt tikai aicinātas pārrunāt ar PSRS iespēju izveidot Baltijas reǵionā no atomieročiem brīvu teritoriju, kā arī dažādos forumos iniciēt situācijas izvērtējumu Baltijas valstīs attiecībā uz cilvēktiesību normu ievērošanu. ${ }^{40}$

Kug̣a brauciens noslēdzās Stokholmas ostā 29. jūlija priekšpusdienā, taču vairāki saistītie pasākumi turpinājās vēl arī 29. jūlijā

36 Baltiešu dienas Skandināvijā 1985, 13.

37 Brīvības kuǵa polītiskā nozīme 1985.

38 Helsinki International Service in Finnish zinu apkopojums LD281846 (28.07.1985). IHRC, kolekcija: Baltic tribunal, mape: Radio Report manuscripts.

39 Radio Free Europe / Radio Liberty B-wire news report "Finnish press reaction to Baltic cruise" (01.08.1985) (turpat).

40 Radio Free Europe / Radio Liberty B-wire news report "Baltic Resolution text" (29.07.1985) (turpat). un nākamajās dienās. 29. jūlijā notika kuğa brauciena dalībnieku mītinš Stokholmas pilsētas centrā, kura dalībniekus uzrunāja vairāku Zviedrijas politisko partiju (Zviedrijas liberālās partijas, Zviedrijas konservatīvās partijas u. c.) pārstāvji. ${ }^{41}$ Savukārt 30. un 31. jūlijā Stokholmas Universitātē notika Baltijas nākotnes seminārs, kurā piedalījās ap 200 dalībnieku - gan baltieši, gan arī zinātnieki no Zviedrijas, ASV, Lielbritānijas un Vācijas. Semināra dalībnieki - vēsturnieki, politologi un militārās drošības eksperti - divu dienu garumā sprieda par iespējamajiem Baltijas reǵiona nākotnes attīstības variantiem, pieskaroties tādiem jautājumiem kā eventuālu pārmaiņu Baltijas valstīs ietekme uz pārējām regiiona valstīm, reǵiona valstu attieksme pret baltiešu prasībām, baltiešu iespējas iespaidot politisko situāciju u. tml. ${ }^{42}$

\section{PSRS reakcija}

Kug̣a akcijas publicitāti lielā mērā sekmēja tieši izteiktā PSRS reakcija. Padomju Savienība veltīja šai baltiešu jauniešu organizētajai akcijai gan kritizējošus rakstus, gan uzbrūkošus un apvainojošus informācijas ağentūras TASS paziņojumus. TASS paziņojums 1985. gada 15. jūlijā lietoja dzēlīgus vārdus gan par Kopenhāgenas tribunālu, kas notika tieši pirms kug̣a brauciena, gan arī pašu Baltijas brīvības un miera kuǵa akciju. Baltic Star tika nosaukts par "speciāli nōirētu pirātu kug̣i", no kura Somijas galvaspilsētā krastā izkāpšot "bandītu bars". ${ }^{43}$ Paziñojumā minēts arī, ka kuğa dalībnieki, braucot gar PSRS jūras robežu, paredzējuši nogādāt Baltijas valstīs lielu daudzumu pretpadomju materiālu, izmantojot šim nolūkam speciālus negrimstošus konteinerus un gaisa balonus. Kā pretpadomju materiālu avots un abu akciju īstenotājs norādīta ASV Centrālā izlūkošanas pārvalde (CIP) un "NATO reakcionārās aprindas", kuras vēlas "padarīt vēl saspringtāku esošo situāciju

\footnotetext{
41 Radio Free Europe / Radio Liberty A-wire news report "Intro Baltic" (29.07.1985) (turpat).

42 Bērztīsa 1985, 1.

43 TASS in English (15.07.1985). Māra Graudina personīgais arhīvs.
} 
pasaulē" ${ }^{44}$. Šādi un līdzīgi PSRS izteikumi norādīja uz zināmas problēmas esamību Baltijas valstīs un radīja izbrīnu Rietumu sabiedrībā. Londonas avīze The Times atzīmēja, ka šāds pārspīlēts jūtīgums "ir labākais indikators, ka pārmaiņas Baltijas republikās nemaz nav tik neiespējamas, kā šobrīd šksiet”45.

Kuǵa braucienam uzmanību pievērsa arī Latvijas PSR Ārlietu ministrija, izplatot Latvijas žurnālistiem savu interpretāciju, kā "pareizi" attiekties pret šo braucienu. ${ }^{46}$ Raksti par kuğa braucienu parādījās arī Latvijas PSR oficiālajā laikrakstā krievu valodā Sovetskaja Latvija.

PSRS izteiktos pārmetumus kruīza rīkotāji atspēkoja, norādot, ka piln̄̄gi noteikti neizmantos kug̣a braucienu radio raidījumu noraidīšanai uz Baltiju vai arī drukātu propagandas materiālu nogādāšanai Baltijas valstīs ar balonu vai peldošu konteineru palīdzību un vispār izvairīsies veikt jebkādas darbības, kas varētu kalpot par ieganstu padomju robežapsardzes spēkiem apturēt kug̣i vai mēǵināt uzkāpt uz kuğa. Organizatori noraidīja arī viedokli, ka kuğa akciju apmaksā Rietumvalstu specdienesti. Kā vienu no iespējamajiem izskaidrojumiem PSRS pārliecībai par specdienestu finansējuma iesaisti kuğa brauciena organizatori minēja domu, ka, iespējams, PSRS neapzinās, ka baltieši rietumos kopumā ir materiāli visnotaḷ labi nodrošināta sabiedrības grupa. ${ }^{47}$ N̦emot vērā PSRS izteiktos pārmetumus un brīdinājumus, pirms kug̣a izbraukšanas gan pašu kuǵi, gan arī brauciena dalībnieku bagāžu pārbaudīja Zviedrijas policija, un, tā kā nekas aizdomīgs vai miermīlīgai akcijai nepiemērots netika atrasts, kugíis uzsāka braucienu, kā plānots. $^{48}$

Papildu uzmanību kuǵim piesaistīja vairāki incidenti brauciena gaitā. Ziṇa par bumbu pie akcijas rīkotāju biroja Stokholmā un uz kuǵa pirms tā izbraukšanas, kā arī padomju

44 Turpat.

45 Brown 1985.

46 Gudra ārpolitika 1993.

47 Radio Free Europe / Radio Liberty B-wire news report (24.07.1985). IHRC, kolekcija: Baltic tribunal, mape: Radio Report manuscripts.

48 Radio Free Europe / Radio Liberty A-wire news report (27.07.1985) (turpat). patruḷkuǵu agresīvie manevri kuǵa tuvumā brauciena laikā radīja papildu interesi par braucienu un tā norisi ${ }^{49}$ Kug̣a īpašnieks gan sarunā ar žurnālistiem noraidīja izskanējušās baumas, ka kuğis it kā saņēmis uzspridzināšanas draudus, bet apstiprināja, ka izjutis zināmu padomju spiedienu atcelt paredzēto braucienu. ${ }^{50}$

\section{Rezultāti un ietekme}

Baltijas Brīvības un miera kuǵa brauciens ieguva ḷoti plašu publicitāti, to pieminēja vairāk nekā 2000 rakstu dažādu valstu presē, kā arī daudzi radio un televīzijas raidījumi vairākās valstīs. Publikācijām tieši par pašu kuğa braucienu sekoja arī virkne saistītu rakstu par Baltijas valstīm kopumā, intervijas ar baltiešu trimdiniekiem, kā arī vairāki desmiti atbildes publikāciju un paziņojumu no PSRS puses.

Par kuǵa braucienu plaši rakstīja to Skandināvijas valstu prese, kurās iegriezās kuğa maršruts, kā arī vispār Eiropas prese. Taču reportāžas par kuǵa braucienu un plašākas publikācijas parādījās arī tādās no Baltijas jūras tālās valstīs kā Argentīna, Brazīlija, Austrālija, Saūda Arābija, Japāna u. c. Pēc formas un satura minētās publikācijas iespējams iedalīt vairākās grupās. Brīvības un miera kug̣i pieminēja lielo preses aǵentūru, dažādu valstu nacionālo laikrakstu redakciju, kā arī brīvo žurnālistu ziņās un rakstos. Pēc satura šie raksti ziņoja par pašu kuğa braucienu vai rakstīja par Baltiju kopumā, par Baltijas tautām un to likteni. ${ }^{51}$

Tāpat par kuǵa braucienu ziņoja dažādu valstu radio un televīzijas dienesti. Radio Brīvā Eiropa / Radio Brīvība (Radio Free Europe / Radio Liberty) katru dienu no kugga klāja raidīja nelielas tiešraides. ${ }^{52}$ Reportāžu no demonstrācijas Helsinkos 28. jūlijā raidīja Somijas radio raidījums Radio Magazine..$^{53}$

49 Graudiňš 2011, 242.

50 Radio Free Europe / Radio Liberty B-wire news report (27.07.1985). IHRC, kolekcija: Baltic tribunal, mape Radio Report manuscripts.

${ }^{51}$ Bērziņš, Teness 2011, 261.

52 Report to the World Baltic Conference (05.09.1985). LNA LVA, 2253-1-16, 10.

$53 \mathrm{Sk}$. raidījuma teksta atšifrējumu: Helsinki International Service in Finnish zingu apkopojums LD281846 (28.07.1985). IHRC, kolekcija: 
Vērtējot Baltijas brīvības un miera kuğa akcijas rezultātus un ietekmi, ASV dzivojošais lietuviešu izcelsmes publicists Viktors Naks (Victor A. Nakas) šo akciju nodēvējis par "radošāko un efektīvāko publisko attiecību kampaṇu, kādu jebkad veikuši diasporas baltieši" ${ }^{54}$. Tā neapšaubāmi bija viena no rūpīgāk izplānotajām un publicitātes ziṇā veiksmīgākajām latviešu trimdas akcijām. Līdzīgā apjomā un vairāk nekā par Brīvības un miera kug̣i par Baltijas valstīm pasaules prese ziņoja vēl tikai Baltijas valstu neatkarības atgūšanas periodā. Ziņas par kuǵa braucienu un tā dalībnieku izvirzītajām problēmām parādījās visdažādāko valstu medijos visos kontinentos. Ši akcija "izvirzīja Baltijas neatkarības jautājumu laikrakstu pirmajās lapaspusēs laikā, kad tikai retais, izņemot pašus baltiešus, uzskatīja, ka šāds jautājums vispār eksistē" ${ }^{55}$.

Jāatzīmē arī Baltijas brīvības un miera kuğa brauciena zināma ietekme uz Somijas un Zviedrijas sabiedrisko domu un attieksmi pret PSRS un Baltijas valstīm. ${ }^{56}$

\section{Nobeigumam}

Atškiirībā no daudzām citām iepriekš trimdas laikā notikušām politiskām akcijām, Baltijas brīvības un miera kug̣is nebija atbildes reakcija uz kāda Latvijai nozīmīga vēsturiska notikuma kārtējo gadadienu vai kādu politisku notikumu, Rietumvalsts pienemtu lēmumu vai padomju amatpersonas ierašanos vizītē Rietumos. Abas viena pēc otras notikušās akcijas - Kopenhāgenas tribunāls un kuǵa brauciens - bija jauns sasniegums trimdas politisko aktivitāšu vēsturē: aktīva, trimdas iniciēta politiska akcija starptautiskā mērogā, kas balstījās tieši uz trimdas jauniešu pašiniciatīvu un vēlmi aktīvi paust viedokli par notiekošo Baltijas valstīs un piesaistīt tam pasaules uzmanību.

Kug̣a brauciena akcija, pateicoties tās veiksmīgajai publicitātes stratēǵijai un l,oti plašajam un tolaik l̦oti aktuālajam jautājumu

Baltic tribunal, mape: Radio Report manuscripts.

54 Nakas 1985.

55 Kalniņš 2005.

56 Sīkāk sk. Graudinšs 2011, 247-248. lokam, kurus šì akcija uzrunāja (vides problēmas, bruṇošanās ar atomieročiem u. tml.), sasaistot tos ar situāciju Baltijas valstīs, panāca ievērojamu pasaules mediju uzmanību. Sava nozīme brauciena panākumos bija tā piesaistei Helsinku Nobeiguma akta parakstǐšanas desmitgadei un, kā norādījusi L. Zaḷkalne, arī labi izvēlētam gadalaikam, proti, tas notika vasaras vidū, kad medijiem parasti ir mazāk aktuālu ziņu. ${ }^{57}$ Kuǵa akcijas aktualizētie un apspriešanai izvēlētie jautājumi bija svarīgi ne vien Baltijas valstīm, bet arī visā pasaulē, kas veicināja to plašāku apspriešanu medijos un sabiedrīibā. Salīdzinot šîs akcijas iegūto publicitāti ar citām, iepriekšējās desmitgadēs trimdā īstenotām plašām politiskām akcijām, gan ir jāṇem arī vērā tehnologiju attīstība un informācijas aprites uzlabošanās, kuru rezultātā 80. gadu vidū ziņas par Baltijas brīvības un miera kuǵa akciju varēja operatīvi izplatīties visā pasaulē. Vēl, piem., 60. gadu vidū līdzīga pasākuma ātra un plaša publicitāte vispār nebūtu iespējama.

Baltijas brīvības un miera kuğa brauciens pelnīti ir ticis dēvēts par atmodas priekšvēstnesi. Šĩ akcija spilgti demonstrēja notiekošās pārmaiņas arī trimdas politiskās darbības raksturā. Tā zināmā mērā noslēdz trimdas aukstā kara paisumu un bēgumu determinēto politiskā lobija centienu periodu mītnes zemēs un iezīmē pāreju uz atmodas laikam raksturīgajiem trimdas politiskās darbības pan̄ēmieniem, ieskaitot proaktīvu rīcību un pasaules sabiedriskajai domai aktuālu argumentu izmantošanu.

Kopumā Baltijas brīvības un miera kug̣is bija prasmīgi rīkota publicitātes akcija, kura izcēla Baltijas valstu jautājumu pasaules sabiedrības uzmanības lokā.

Raksts tapis valsts pētījumu programmas Latvijas mantojums un nākotnes izaicinājumi valsts ilgtspējai projektā Indivīda, sabiedrības un valsts mijiedarbība kopējā Latvijas vēstures procesā: vērtību konflikti un kopīgu vērtību veidošanās vēsturiskos lüzuma punktos (projekta Nr. VPP-IZM-2018/1-0018).

\footnotetext{
57 Zaḷkalne 2005.
} 


\section{VĒRES}

Baltiešu brīvības un miera kuğis (1984) ELJA Informācija, 102 (01.07.1984.), 79-80.

Baltiešu dienas Skandināvijā: Lielo notikumu hronologija (1985) Vēja Zvani, 16, 12.

Bērziṇš, U.; Teness, V. (2011) Baltijas brīvības un miera kuǵis - Rietumu pasaules vērtējums. Latviešu trimdas loma Latvijas neatkarības idejas uzturēšanā: Apvienotā pasaules latviešu zinātnieku III un Letonikas IV kongresa sekcijas materiāli. Rīga : Latvijas Zinātņu akadēmija.

Bērztīsa, M. (1985) Pirmais Baltijas nākotnes seminārs. Laiks (11.09.1985.).

Bohuslawsky, M. (1985) Wave of resistance born on high seas. Toronto Sun (30.07.1985.).

Brīvības kug̣a polīitiskā nozīme (1985) Laiks (17.08.1985.).

Brown, A. (1985) Why the Balts can live in hope. The Times (02.08.1985.).

Cipulis, A.; Brancis, M. (sast.) (2001) Pasaules brīvo latviešu apvienības darbības apskats 1956-2001: Rakstu un materiālu krājums. Rīga : Latvijas Valsts arhīvs.

Ekmanis, R. (2007) Starptautiskie raidījumi latviešu valodā 20. gs. otrā pusē. Jaunā Gaita, 250, 251.

Graudiņš, M. (1985) Brīvības kugís gaida dalībniekus. Latvija (29.04.1985.).

Graudiņš, M. (2011) Baltijas brīvības un miera kuğis - Atmodas priekšgājējs. Latviešu trimdas loma Latvijas neatkarības idejas uzturēěanā: Apvienotā pasaules latviešsu zinātnieku III un Letonikas IV kongresa sekcijas materiāli. Rīga : Latvijas Zinātṇu akadēmija.

Gudra ārpolitika - mūsu drošības ḳ̄la (1993) Zvaigzne, 1, 5.

Kalniņš, O. (2005) Baltic Peace and Freedom Cruise remembered. Pieejams: http://www.li.lv/en/?id= 46\&news $=61$ (20.06.2011.).

Liepiṇa, A. (red.) (1995) Laiks, telpa, l̦audis: Daugavas Vanagu organizācijas desmit gadi 1983-1992, 5. Toronto : DV CV.

Nakas, V. A. (1985) The Beginnings of a Baltic-Scandinavian Understanding. Pieejams: http://www. lituanus. org/1985/85_4_05.htm (13.05.2020.).

Nyet Nyet Soviet: Stāsti par latviešu politiskajām demonstrācijām trimdā (2018) Rīga : Muzejs un pētniecības centrs "Latvieši Pasaulē".

PBLA Brīvības nedēlas izlozes laimētāji (1985) Laiks (26.06.1985.).

Zaḷkalne, L. (2005) 1985 - Baltijas valstis atgriežas pasaules kartē. Jaunā Gaita, 241, 45-46. 